\title{
RISK BEHAVIOR IN THE TRANSMISSION MECHANISM OF MONETARY POLICY IN INDONESIA
}

\author{
Doni Satria ${ }^{1}$ \\ Solikin M. Juhro*
}

\begin{abstract}
This study explores interconnections between risk behavior in the financial sector, particularly banking sector, with monetary policy stance. Referring Bernanke and Blinder (1988) modified model for analyzing the bank credit behavior, we develop an empirical model to test the role of risk behavior in monetary policy transmission mechanism. Vector Error Correction Model is applied to test the significance of interaction between risk variables and monetary policy stance in the short run dynamics of credit behavior around its long-run co-integration with real GDP. Some empirical results emerge from this preliminary study. First, there is early indication that risk taking channel in the monetary policy transmission mechanism exists in Indonesia during analysis period. Second, risk variables and credit tend to move pro-cyclically while monetary policy stance tends to a-cyclical. Third, pro-cyclical behavior of credit and risk variables reverses the effect of loose monetary policy stance, and there is an indication of asymmetric effect between tight monetary policy and loose monetary policy in Indonesian economy. These empirical findings bring about policy recommendations for better understanding on the risk behavior in the banking sector, as well as integration between monetary and financial sector policies.
\end{abstract}

Keyword: Monetary Policy Transmission Mechanism, Monetary Policy Stance, Banking Risk Behavior, Risk Perception.

JEL Code : E52, E58

1 Lecturer in Faculty of Economy, Universitas Negeri Padang.

**Economic Analyst of Bank Indonesia and Lecturer in Post graduate program, Faculty of Economy, Universitas Indonesia. This study covers the personal opinion and does not represent the opinion of the institution in which the authors work. 


\section{INTRODUCTION}

The effect of risk behaviors on the dynamics of the financial sector is a considerable research issue today, particularly associated with the effectiveness of responsive measures taken against the global financial crisis that occurred since mid-2007. Some arguments are built to see the fundamental factors behind the financial crisis that is suspected as the unprecedented crisis, both in terms of level of influence as well as its time flow. Taylor (2009) argued that the crisis is caused by the central bank's policy that tends to maintain the interest rate too low, as the consequence of the low levels of inflation in a long period, prior the crisis. Taylor explained that the central banks in developed countries do not take into account the risk in the banking and finance sector in their monetary policy reaction function, causing the setting of the nominal interest not in an appropriate rate (too low). The implication of this analysis showed the interaction between the stances of monetary policy by central banks against the losses in the financial sector, especially banking. While Mishkin (2009) argued that the effectiveness of the monetary policy tends to be more potential during the days of the crisis than the normal conditions, thus providing the foundation for macroeconomic risk management to deal with economic contraction during the crisis period.

The above facts show that there are linkages between monetary stability with the stability of the financial sector. The way monetary authority should respond and act in carrying out monetary policy is generally understood and is relatively not much debated among economists. However, in terms on how the monetary authority should respond and act against problems that arise from the financial sector is still a debatable among economists (Goodhart and Tsomocos, 2007). For monetary authorities, the target of the running monetary policy will be more easily achieved if the stability of the financial sector works well. Meanwhile, if the condition of macroeconomic fundamentals is not stable, it would cause turmoil within the financial sector in the economy.

The linkage between monetary stability with the stability of the financial sector will finally become a central issue in an effort to see relationship between the measures taken, risk behaviors, and the course of a financial crisis. Research by Nier and Zicchino (2008) suggests that the bank credit supply is influenced by the stance of monetary policy that interacts with the pressure on bank balance sheet stress, transmitted through the bank's losses. The study concluded that the impact of the stance interaction of monetary policy with bank losses become stronger in periods of crisis, under assumption that the amount of risk of the financial sector is higher in economy with crisis, implying that the financial sector risk factors interact with the stance of monetary policy. For the case of Canada, Li and St-Amant (2010) found that a restricted or contractive monetary policy has a stronger impact on output than an expansive monetary policy and that 
expansive monetary policy has a stronger impact than the contractive monetary policy when the economy is in the conditions of high financial stress (risk).

Furthermore, Borio (2008) argues the importance of path analysis of risk-taking channel in the transmission mechanism of monetary policy. This is different from the bank lending channel proposed by Bernanke and Blinder (1988) and Bernanke and Gertler (1995) who argued that monetary policy works through bank reserves and further affects the supply of bank credit in the economy. Risk-taking channel affects the supply of credit by banks through the bank's decision to distribute credit based on the changes in bank behavior towards the credit risk. Adrian and Shin (2009) suggested that risk taking this channel is also different from the concept of the financial accelerator, marked by Bernanke and Gertler (1999). Related to that, the results of empirical research provide enough evidence of the existence of risk taking channel in transmission mechanism of the monetary policy².

In the context of the Indonesian economy, the observation on the role of risk factors in the financial sector in the operation of the transmission mechanism has not been done in depth. Goeltom et al. (2009) generally concludes that based on the empirical analysis, risk perception play a significant role in transmitting monetary policy in Indonesia. Based on the conditions and the complexity of Bank Indonesia in conducting their monetary policies, this study identifies the problem of asymmetric effects of monetary policy. Asymmetrical conditions are influenced by the behavior of the financial sector which tends to be pro-cyclical and the existence of risk taking channel as proposed by Borio and Zhu (2008). The result of the conducted analysis is still a preliminary analysis using the swap premium as an indicator of risk perception in general. These results suggest further analysis using analytical models and better indicators and empirical models that are capable of capturing the existence of the role of risk and risk perception in the financial sector in transmitting the monetary policy in Indonesia.

Associated with some thoughts above, in line with the dynamics and the structural changes in the Indonesian economy post-1998 economic crisis, the stability management of monetary and financial sector still faces problems of rigidity of lending rates distributed by banks to the economy, which means that the development of interest rates of financial market has not fully responded the dynamic of BI policy rate. Several observations showed that the spread between the policy interest rate with the cost of funds tends to decline, but at the same time the spread of policy interest rate policy with base loan interest rate (Suku Bunga Dasar Kredit/SBDK) tends to increase. SBDK has various components, one of which is the premium of banking risk (Bank Indonesia, 2010).

2 See Gambacorta, 2009 and the reference cited. 
The explanation above indirectly indicates an interaction between the monetary policy and the risk in the banking sector, which is transmitted to the real economy through the supply of bank credit ${ }^{3}$. Indonesia, as a country that does not have a fast growing financial sector as in the developed countries, certainly does not have yet an alternative investment financing and the role of the banking sector in the financial sector is very dominant. The study to understand how the impact of banking risks to the economy of Indonesia is very important in the context of ensuring stability of the financial sector ${ }^{4}$.

This research tries to see the linkage between the risk of the financial sector, particularly in banking, with monetary policy, and its implications toward the transmission mechanism of monetary policy to the real sector in the economy. Until now, most of the analysis of the stability in financial sector focused more on identifying the factors that determine the risk of financial sector and the institutional factors that determine the risk profile in the financial sector. Meanwhile, how the feedback from the changes in risk in the financial sector to real economy is not yet widely modeled (Tieman and Maechler, 2009). By understanding the magnitude of risk change in the financial sector, particularly banks, and their interaction with monetary policy on bank credit supply, this study will provide an illustration of the real impact of changes in risk and risk perceptions in the banking sector as well as the monetary policy (which is a reflection of risk taking behavior of economic actors) on the economy.

This research conducts the empirical model specification by modifying the model developed by Tieman and Maechler (2009). In general, empirical models will test the impact of risk behaviors, reflected in the indicators of risk aversion, economic actors and the level of risk in the banking industry, which interact with the stance of monetary policy on bank credit supply. Some of the main conclusions drawn from this study are that the risk perceptions of economic actors and the level of risk in the banking sector have a significant role in transmitting monetary policy through credit channels in Indonesia. In this case, the role of risk perceptions of economic actors and the level of risk in the banking sector when interacting with the monetary policy stance led to the reversal of direction of the impact on the loose monetary policy. Conversely, the restricted monetary policy stance to trigger the contraction of economy through bank credit channels becomes ineffective when interacting with the risk perception variable of economic actors and the level of risk in the banking sector.

3 Credit channel in monetary policy transmission mechanism was introduced firstly by Bernanke and Blinder (1988). The analysis on how the credit supply from bank is affected by monetary policy in several ways, has been done by many economist for the last 2 decades and is an active research on economic field. . The monetary policy transmission through banking credit includes so far are, liquidity channel (Diamond dan Rajan, 2006), Bank Capital Channel (Van der Hauvel, 2007), Risk taking channel (Borio, 2008 and Adrian and Shin, 2009). These three channel influence the real economi through the changes of the banking credit, , which furhter affect the real investment and consumption.

4 The literatures tends to analyze the the determinant of bank risk, however pay less attention on how the bank risk affect the real economy transmitted via the bank credit supply. 
This paper consists of five parts. Connecting the background of this part, the second section will present briefly the theoretical basis associated with the balance of the credit markets and the role of risk variables as the driving and towing factors of the bank credit expansion. The third section will describe the research methodology, particularly in the development of empirical models, estimated with the method of Vector Error Correction Model (ECM). The next section will present the results of the assessment and the impact analysis of risk variables and the stance of monetary policy on bank credit growth dynamics. The concluding section will present some conclusions and policy implications.

\section{THEORY}

Bank or financial intermediary institution in the economy is believed to play a very important role in transmitting the effects of monetary policy by most economists, but the way the banks transmitting the monetary policy to the real economy has still not obtained a consensus from economist and is still a very important research object in monetary economics. The initial approach in explaining the role of banks in transmitting monetary policy is believed to be through the money or liabilities of the banking sector to the economy (money view), which then developed into the idea that the banks affect the economy through a line of credit (Bernanke and Blinder, 1988). Through the credit channel, it is believed that the monetary policy can affect the economy through credit supply from the banking sector or the bank lending channel, and through the company's balance sheet where the monetary policy affects the capability of companies to obtain external financing from banks or balance sheet channel (Bernanke and Gertler, 1995).

Based on the initial theoretical model developed by Bernanke and Blinder (BB), the development of theoretical models to include the role of financial sector risk can be conducted, especially from the banking sector in analyzing the existence of risk channel in the transmission mechanism of monetary policy. The development of a simple dynamic model based on the model of BB, as developed by Escandon and Diaz-Bautista (2000) and Walsh (1998) can be used as the baseline in developing empirical models to be used in this study.

In the dynamic version, the curve of commodity and credit demand, ' $C C^{\prime}$, in the $\mathrm{BB}$ model is transformed into the short-term and the long term adjustment process between aggregate supply and demand in the real sector ${ }^{5}$. Because the price is assumed fixed, then the

5 Standard IS-LM model explained on the macroeconomic textbooks assume perfect substitution between bonds and bank credit. Bernanke dan Blinder (BB) release this assumption and formulate the IS-LM equilibrium with explicite bank credit market.. On BB model, the bank credit demand is a function of lending rate, market rate (equal to the bond yield rate) and the income. This way, the CC curve replace the IS curve. (See Bernanke and Blinder, 1988) 
short-term adjustment occurs through the mechanism of excess demand that causes the output to be back into the equilibrium. This condition can be written as follows:

$$
\dot{y}=\beta\left(y^{d}-y\right) \quad \beta>0,
$$

As in the BB aggregate demand model $\left(y^{d}\right)$ is determined by the banking interest rates, market interest rates, and fiscal policy. As well as the BB model, the market interest rate is determined by monetary policy (Bank reserve, R) and money demand $\left(M^{d}\right)$, then:

$$
\begin{array}{ll}
y^{d}=f(\rho, G, i) & f_{\rho}<0, f_{G}>0, f_{i}<0, \\
i=h\left(R, M^{d}\right) & h_{R}<0, f_{M d}>0,
\end{array}
$$

The dynamics of the financial sector comes from the movement of banking credit interest rate $(\rho)$ which balances the banking credit market. With the assumption of no credit rationing, this variable will adjust the excess demand and the excess supply in the banking credit market, so that:

$$
\begin{array}{ll}
\dot{\rho}=\alpha\left(L^{d}-L^{s}\right) & \alpha>0 \\
L^{d}=L\left(\rho, i, y, \sigma^{d}\right) & L_{\rho}<0, L_{i}>0, L_{y}>0, L_{\sigma^{d}}<0 \\
L^{s}=\lambda\left(\rho, i, \sigma^{s}\right) & \lambda_{\rho}>0, \lambda_{i}<0, \lambda_{\sigma}<0
\end{array}
$$

The equation (4) to (6) show the condition of equilibrium within the banking credit market through the mechanism of banking credit price adjustment (credit interest rate), while credit demand is determined by banking credit interest rate, the markets interest rate on the bonds, the level of real economy, and the risk credit of the demand side. Furthermore, the bank credit supply is affected by the banking credit interest rate, bonds market interest rate and the risk level of banking credit allocation.

In addition to the risk variables, all the variables included in the analysis model, which was developed based on the model proposed by Escandon and Diaz-Bautista (2000), are similar to BB model (1988). In their analysis, Escandon and Diaz-Bautista did not explain the theoretical basis to enter the risk variable of the credit demand and supply in this model. Further explanation justifies the inclusion of the risk variable as the component that affects the supply of credit bank which then interacts with monetary policy developed by Freixas and Jorge (2008) and Disyatat (2010). 
The dynamics of the model represented by equation (1) to (6) can be explained as follows. By performing linearization on long-term equilibrium condition for each variable using the first order Taylor expansion series, we will obtain by the dynamics of the real sector by using equation (1) to (4) as follows:

$$
\dot{y}=-\beta(y-\bar{y})+\beta f_{\rho}(\rho-\bar{\rho})+\beta f_{G}(G-\bar{G})+\beta f_{i}(i-\bar{i})
$$

Because it is assumed in equation (1) that $\beta>0$, then, $\dot{y}$ will be stable. So graphically the relationship of $y$ with growth of $y$ can be described as follows:

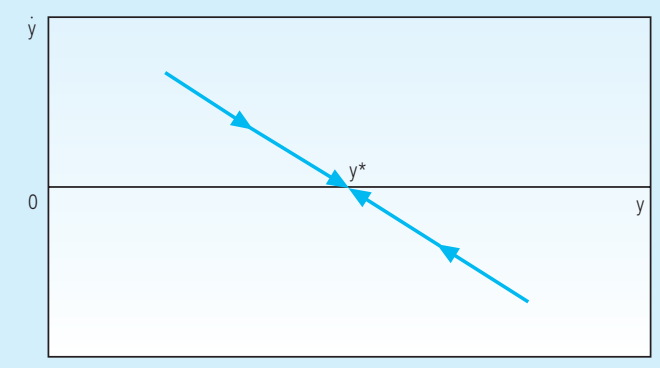

Figure 1.

The Dynamics of Real Sector Growth

Figure 1, shows the relationship between the change of variable $y$ (output of the economy) from time to time $\left(\partial_{y} / \partial_{t}\right)$ with the variable $y$. Because $\beta>0$, then the relationship between changes in $y$, with respect to $t$, with $\mathrm{y}$ is negative. Thus, when the value of growth of the economy's output is greater than zero, then the value of $y$ will continue to increase ( $y$ moves from left to right), vice versa if the growth of output value is less than zero, then the $y$ value would decrease and move from left to right. Because the negative relationship between the growth of $y$ with the value of $y$, then at the point of $y^{*}$, the value of $y$ will be stable. By performing the same steps, the dynamics of the financial sector are:

$$
\begin{aligned}
\dot{\rho}= & \alpha L_{y}(y-\bar{y})+\alpha\left(L_{\rho}-\lambda_{\rho}\right)(\rho-\bar{\rho})+\alpha\left(L_{i}-\lambda_{i}\right)(i-\bar{i}) \\
& +\alpha L_{\sigma^{d}}\left(\sigma^{d}-\bar{\sigma}^{d}\right)-\alpha \lambda_{\sigma^{s}}\left(\sigma^{s}-\bar{\sigma}^{s}\right)
\end{aligned}
$$


Because $\alpha>0\left(L_{\rho}, \lambda_{\rho}\right)<0$ and, then $\dot{\rho}$ will be stable:

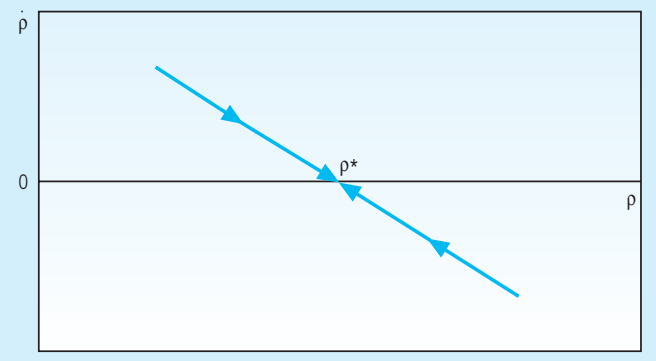

Figure 2. The Dynamics of the Change of Financial Sector

Based on figure 2 , assuming that $\left(L_{\rho}-\lambda_{\rho}\right)<0$, then the relationship between $\rho$ with $\dot{\rho}$ will be negative. For each positive or negative value of $\dot{\rho}$ will cause the value of $\rho$ to fall or rise (larger or smaller). Consequently in the long term, the value of $r$ will be constant at the time when $\dot{\rho}=0$ at the point of $\rho^{\star}$. Figure 1 and 2 shows the process towards the balance in goods and services markets and the banking credit market. In the model used by the BB (1988) exogenous changes in the balance of the credit markets (with imperfect substitution between credit markets and capital markets) can alter the balance in the economy.

Furthermore, in developing the hypotheses to determine the impact of each variable to the exogenous change of variable risk in the bank credit disbursements, the matrix solutions is used for the both equation in the following system of differential equations:

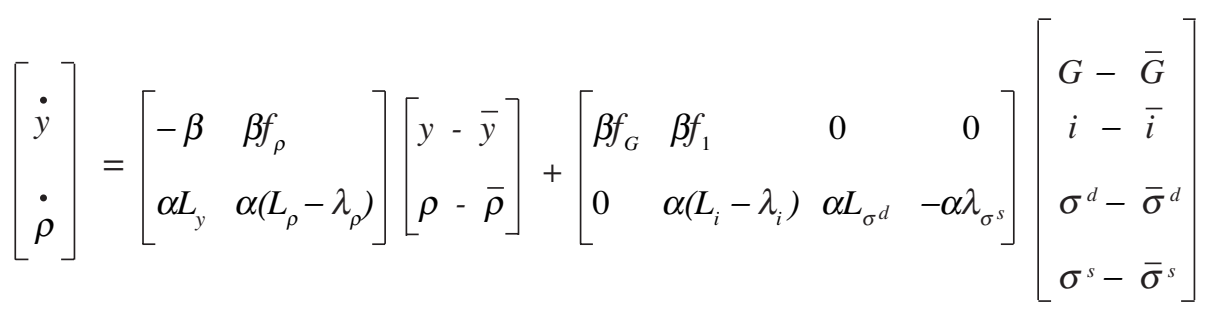

Graphical representation using the diagram phase of a dynamic shift in the banking credit interest rate and income (GDP) variable is shown in Figure 3. Figure 2 is the merge of figure 2 and 2 images that can be analyzed in two axes that shows the relationship between $y$ and $\rho$ at the time and are equal to zero. Based on equations II.7 and II.8, when the balance is at the point of $\rho^{\star}$ the relation between $\rho$ and $y$ is positive, and at the point of $y^{\star}$ the relationship 
between $\rho$ and $y$ is negative. By using the explanation presented in the figure 1 and 2 , then for each economic condition that is not in equilibrium in the credit markets and markets of goods and services, the economy is heading the long run equilibrium at the point of $\rho^{\star}$ and $y^{\star}$. In this model, it is showed that exogenous changes in the variables $G, i$ (interest rate in the capital markets), $\sigma^{d}$ (risk of financial sector on the demand side) and $\sigma^{s}$ (the risk of financial sector on the supply side) will cause a shift from long term equilibrium through the shift of balance in the model (point $e_{0}$ ).

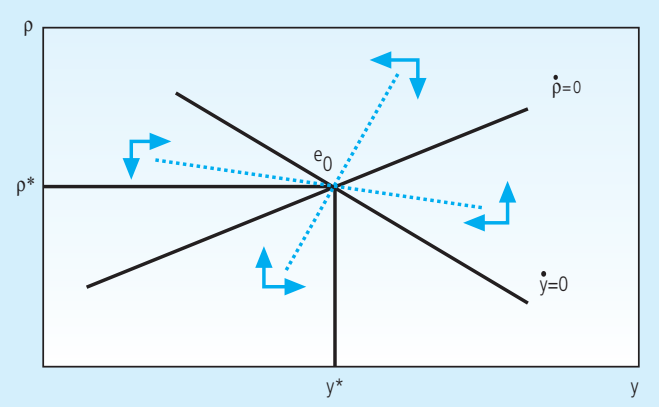

Figure 3. The Dynamics of General Equilibrium in Economy

The graphic suggests that this developed model is dynamically stable and indicates that the economy will lead to a long-term equilibrium. The theoretical foundation in this model can provide the solution as a tool to form hypotheses from economic theory to be tested by using the empirical models. In the long term, the economic variables will lead to a new equilibrium after the shock that occurred on exogenous variables. In this model, those that are defined as exogenous variable are fiscal policy $(G)$, monetary policy $(R)$ and risk variables $(\sigma)$. The partial impact of each exogenous variable is as follows:

$$
\left.\frac{\partial_{y}}{\partial_{G}}\right|_{y^{\circ}=0}=f_{G}>0 \quad ;\left.\quad \frac{\partial_{y}}{\partial_{G}}\right|_{\rho=0}=0
$$

The increase in government spending (fiscal policy) has a positive impact on long-term equilibrium GDP (output) directly through the increased real demand in the economy, thus the curve $\dot{y}=0$ must be shifted to right, while the curve $\dot{\rho}=0$ is not affected as the government spending $(G)$ does not directly influence the financial sector. 


$$
\left.\frac{\partial y}{\partial i}\right|_{\dot{y}=0}=f_{i}<0 ;\left.\quad \frac{\partial y}{\partial i}\right|_{\dot{\rho}=0}=\frac{-\left(L_{i}-\lambda_{i}\right)}{L_{y}}<0
$$

Based on the assumptions in equation (3), the monetary policy conducted by the Central Bank, for example by purchasing the securities with the instrument of open market operations, will increase the amount of bank reserves. These policies will increase the supply of bank credit, lower the cost of loan funds from bank, and thus encourage the increased production in the economy. In order to attain this condition, the curve $\dot{y}=0$ and $\dot{\rho}=0$ have to shift right and shift the curve $\dot{\rho}=0$ should be proportionately larger.

$$
\begin{aligned}
& \left.\frac{\partial y}{\partial \sigma^{s}}\right|_{\dot{y}=0}=0 \quad ;\left.\quad \frac{\partial y}{\partial \sigma^{s}}\right|_{\dot{\rho}=0}=\frac{\lambda_{\sigma^{s}}}{L_{y}}<0 \\
& \left.\frac{\partial y}{\partial \sigma^{d}}\right|_{\dot{y}=0}=0 \quad ;\left.\quad \frac{\partial y}{\partial \sigma^{d}}\right|_{\dot{\rho}=0}=\frac{-L_{\sigma^{d}}}{L_{y}}>0
\end{aligned}
$$

Exogenous shocks originating from the change in the risk of supply and demand of bank credit in this model have important implications to the economy that is transmitted through the shift in the balance in the bank credit market. If an increase in the risks faced by banks, the risk on the supply side of banking credit will also rise, increasing the cost of banking credit, thereby reducing the level of production (GDP or output) of economy in the long term. Graphically this condition can be described as a shift in the curve $\dot{\rho}=0$.

Freixas and Jorge (2008), develops then a theoretical model of the works of transmission mechanism of monetary policy through the risk by using a partial equilibrium approach in the interbank money market. Broadly speaking, it's described within these models the monetary policy run by the Central Bank that will affect the availability of liquidity in the interbank money market, subsequently forcing the banks that lack liquidity to rationalize the loans addressed to their customers (the occurrence of credit rationing), so it will cause an increase or decrease in production of real sector. Imperfect information in the interbank money market is the source of the emergence of existing risks in the interbank money market. Thus causing the impact imposed by the monetary policy to have greater magnitude, compared within a condition where there is perfect information in the mechanism of inter-bank money market. This theoretical model justifies the works of the transmission mechanism of monetary policy through bank credit channels without having to assume that the credit rationing behavior is absent in the banking 
credit market. So the hypotheses, generated based on solutions in a dynamic version of the previous BB models, can still be used in this study.

The development of risk models in the credit channel in the monetary policy mechanism described by Disyatat (2010) also produces relatively the same conclusion with the model proposed by Freixas and Jorge (2008). In that proposed model, the mechanism of risk acts as the driving and pulling factors of the banking credit expansion. The conclusions generated by both models differ with initial conclusion with the model proposed by Bernanke and Blinder (1988). In the BB model, the monetary policy works and affect the amount of bank loans channeled through a reduction in the number of deposits (and bank reserves) that can be collected by the bank to be distributed as loans to the business world. While in both models, as the empirical facts in economics show that banks can obtain funding sources other than the deposit (e.g. through inter-bank loans), then the working mechanism in the monetary policy to affect bank loans is through changes in the risks faced by banks in obtaining their sources of funding from the interbank money market, while the formation of deposits within the model of Disyatat (2010) is caused by the channeling of credit by banks (inside money). The conclusion of this model shows that the role of bank lending in the transmission of monetary policy becomes important in the economy, although the role of non-bank financial sector as an alternative source of investment funds, other than the bank, has advanced.

\section{METHODOLOGY}

\subsection{Impact of the Real Risks of Banking and Monetary Policy on the Economy}

The theoretical studies indicate that monetary policy has real effects on the economy through the role of banking credit. Furthermore, the literature concerning the transmission mechanism of monetary policy indicates that the role of the financial sector in influencing the economy is through credit channels channeled by banks to the real sector. Based on the results of theoretical stud, it is shown that there is a long-term relationship between the amount of loans distributed by banks with the economy, which, at the level of empirical modeling, indicates a co-integration between the real amount of credit disbursed by the banking sector and the real production in the economy.

The implication of the developed theoretical model revealed that there is a short-term dynamics in risk behavior changes in the supply of banking credit that interact with monetary policy. This condition affects the movement of banking credit disbursed by banks, so that changes of risk behavior from the credit supply side, will have an impact on the economy, at least in the short term, through changes in real credit provided by banking sector. In the empirical 
analysis conducted in this study, two risk behavior indicators in the banking sector will be used. The first indicator provides a measure for the degree of risk averse from the banking sector players in the management of asset, who presumably have already optimally conducted the allocation of assets. The second indicator shows the level of risk in the banking industry.

Thus, the econometric model specification can be used in the specification of Error Correction Model (ECM) as follows:

$$
\begin{aligned}
\Delta \text { Cred }_{t}^{i}= & \alpha\left(\text { Cred }_{t-1}^{i},-\beta_{1} G D P_{t-1}-\beta_{2}\right)+\gamma_{1} \Delta G D P_{t-1}+\gamma_{2} \Delta \text { Cred }_{t-1}^{i}+\gamma_{3} \text { Risk }_{t}^{A}+\gamma_{4} \text { Risk }_{t}{ }_{t}^{D D} \\
& +\gamma_{5, k} \text { Stance }_{t}^{k}+\gamma_{6, k}\left(\text { Risk }^{A} * \text { Stance }^{k}\right)_{t}+\gamma_{7, k}\left(\text { Risk }^{D D} * \text { Stance }^{k}\right)_{t}+\varepsilon_{t}
\end{aligned}
$$

$i=1,2,3$ (Investment Loan, Working Capital Loan and Consumption Loan)

$k=1,2$ (Restricted Monetary Policy Stance and Loose Monetary Policy Stance)

$j=$ time lag, and $t=$ time

Where:

Cred = Real Credit distributed by banking sectors, at the market equilibrium interest rate (investment, working capital and consumption credits)

$G D P=$ Real Gross Domestic Production

Risk $_{t}^{A} \quad=$ Risk perception index of banking sector players

Risk $_{t}^{D D}=$ Risk level of Banking Sector (Distance to Default)

Stance $^{k}=$ Stance size of a monetary policy (restricted or loose)

Equation (12) shows that the change in banking credit is affected by the long-term relationship between two variables that are stationary at the first difference, I (1), real banking credit to the real economy, where the long-term adjustment speed coefficient is a. Furthermore, in the short-term, credit changes are influenced by the economic growth in the previous year, the banking sector risk indicators and risk perceptions of players in the banking sector, the interaction between banking risks and risk perception of banking players with the stance indicator of monetary policy. With the theoretical assumption that in long term there will be a cointegration between credit and GDP, the equation (12) will be estimated by using the VECM, as proposed by Johansen ${ }^{6}$. The benefit using the VECM estimation models is that they allow seeing the impact of error correction term in the short-term dynamics in two-way interaction between credit and GDP in a single modeling system. Thus, it is possible to find out whether

6 See Enders, 2004, hal 362-366. 
the credit is a weakly exogenous variable against GDP. If the estimation indicates that the credit is weakly exogenous variable in short-term dynamics, then the GDP will be used in VECM, meaning that there will be no feedback that occurs from the credit changes toward the dynamics of GDP.

To estimate the equation (12), it requires the variable indicator in banking risk and variable indicators of monetary policy stance. In this study two risk indicators will be calculated and used as independent variables in equation (12). The risk indicator used is the indicator of banking risk and indicator of risk perception of economic actors in the banking sector. The monetary policy stance indicator will be used for the difference between the optimal interest rate for monetary policy (aligned to the empirical calculation for Indonesia), with the actual interest rate. If the monetary policy is too restricting, then the actual interest rate will be higher than the estimated result of optimal interest rate, and vice versa. If the actual interest rate is equal to the estimated result of optimal interest rate, it means that the monetary policy is neutral. The estimated interest rate of this monetary policy is using the Taylor Monetary Policy Rules, where this model and its variations are also used by Bank Indonesia to analyze the monetary policy in Indonesia.

Based on the econometric model in equation (12) the partial impact of the variable of risk perception of players in the banking sector to the dynamics of the credit is

$$
\frac{C r^{i}}{\text { Risk }^{A}}=\gamma_{3}+\gamma_{6, k} \text { stance } e^{k}
$$

The hypothesis testing on the impact of risk perception variable of players in the banking sector to the short-term dynamics of banking credit that interact with the stance of monetary policy, can use:

$$
H_{0}: \gamma_{3}+\gamma_{6, k}=0 \text { and } H_{1}: \gamma_{3}+\gamma_{6, k} \neq 0
$$

The value of $\mathrm{t}$ to calculate the t-statistic in this hypothesis test can be conducted by:

$$
t=\frac{\gamma_{3}+\gamma_{6, k}}{\operatorname{se}\left(\gamma_{3}+\gamma_{6, k}\right)}
$$

The standard deviation (standard error) of equation (14) can not be found by using the estimation equation (12), in order to obtain the required standard deviation value which can be acquired by making the following modifications ${ }^{7}$. If: $\gamma_{3}+\gamma_{6, k}=\theta$, then $\gamma_{3}=\theta-\gamma_{6, k}$, so the modification of equation (12) is:

7 See Wooldridge, 2005. Hal 148-149. 


$$
\begin{aligned}
\Delta \text { Cred }_{t}^{i}= & \alpha\left(\text { Cred }_{t-1}^{i},-\beta_{1} G D P_{t-1}-\beta_{2}\right)+\gamma_{1} \Delta G D P_{t-1}+\gamma_{2} \Delta \text { Cred }_{t-1}^{i}+\left(\theta-\gamma_{6, k}\right) \text { Risk }_{t}^{A}+\gamma_{4} \text { Risk }_{t}^{D D} \\
& +\gamma_{5, k} \text { Stance }_{t}^{k}+\gamma_{6, k}\left(\text { Risk }^{A} * \text { Stance }^{k}\right)_{t}+\gamma_{7, k}\left(\text { Risk }^{D D *} \text { Stance }^{k}\right)_{t}+\varepsilon_{t}
\end{aligned}
$$

Hence:

$$
\begin{aligned}
\Delta \text { Cred }_{t}^{i}= & \alpha\left(\text { Cred }_{t-1}^{i},-\beta_{1} G D P_{t-1}-\beta_{2}\right)+\gamma_{1} \Delta G D P_{t-1}+\gamma_{2} \Delta \text { Cred }_{t-1}^{i}+\theta \text { Risk }_{t}^{A}+\gamma_{4} \text { Risk }_{t}^{D D} \\
& +\gamma_{5, k} \text { Stance }_{t}^{k}+\gamma_{6, k}\left[\left(\text { Risk }^{A} * \text { Stance }^{k}\right)_{t}-\text { Risk }_{t}^{A}\right]+\gamma_{7, k}\left(\text { Risk }^{D D} * \text { Stance }^{k}\right)_{t}+\varepsilon_{t}
\end{aligned}
$$

By using the estimated standard deviation obtained from the coefficients $\theta$ in the equation (15a), we will be able to test the hypothesis by using statistical value of $t$ in equation (14). The hypothesis test with the similar step and method is also conducted to test the partial impact from the banking sector risk (DD) that interacts with the stance of monetary policy.

Furthermore, the partial impact of the monetary policy stance to the short-term dynamics of credit is , $\frac{\partial C r^{i}}{\partial \text { Stance }^{k}}=\gamma_{5, k}+\gamma_{3}$ Risk $^{A}+\gamma_{4}$ Risk $^{D D}$

whose result cannot be analyzed using the assumption of the impact of monetary policy stance when the value of risk variable is equal to zero. By using the average value of risk variable values in the sample, then the estimation result obtained for the impact of monetary policy stance is the impact of monetary policy stance when the risk variable value equals to the average value. The hypotheses testing for the impact of this monetary policy stance can also use the same technique with the test for the impact of risk variables that have been described previously. If the test result for the partial impact of the monetary policy stance, which interacts with the risk variables, is significant, it indicates the evidence of transmission mechanism of monetary policy through the risk channel in the Indonesian economy during the period of analysis.

\subsection{Risk Behavior Indicator in Banking Sector}

As mentioned earlier, this study used two behavioral indicators of risk in the banking sector. The first indicator provides a measure for the degree of risk averse from the banking sector players in asset management who presumably have optimally conducted the allocation of assets. The second indicator shows the risk level in the banking industry as a whole. 


\subsubsection{Risk Perception Indicator of Banking Sector Players}

Risk perception indicator is an indicator that would explain the behavior of banks in assessing the risk based on the asset allocation theory that minimizes the risk, in the assumption that the bank is exercising a risk averse behavior. Assuming that the bank allocates portfolio in the form of non-risky assets at 1-y, then the return of the total bank portfolio is (Bodie. et.al, 2009):

$$
r_{c}=y r_{p}+(1-y) r_{f}
$$

Where:

$r_{c}=$ Return of the total bank portfolio

$r_{p}=$ Return of the risky portfolio

$r_{f}=$ Return of the non-risky portfolio

By using the expectation operator to the equation (16), the expectation toward the total return of the risky and non-risky portfolio allocation is:

$$
E\left(r_{c}\right)=r_{f}+y\left[E\left(r_{p}\right)-r_{f}\right]
$$

By using the assumption of the bank's utility function, the expectation toward the return of the portfolio allocated by the bank is as the following (Bodie, et.al, 2009, page 157):

$$
U=E\left(r_{c}\right)-{ }^{1} /{ }_{2} A \sigma_{c}^{2}
$$

Where $U$ is utility, $r$ is the return of the portfolio, $A$ is the index of the bank's risk aversion, and $\sigma_{c}^{2}$ is a variant of the return of assets. Furthermore, by using the equation (17) the variance of the total assets can be obtained as follows:

$$
\sigma_{c}^{2}=y^{2} \sigma_{p}^{2}
$$

So the optimal allocation of assets by the bank is to maximize the value of utility, which is:

$$
\operatorname{Max} U=E(r)-{ }^{1} /{ }_{2} A \sigma_{c}^{2}=r_{f}+y\left[E\left(r_{p}\right)-r_{f}\right]-{ }^{1} / 2 A y^{2} \sigma_{p}^{2}
$$

The solution for optimal asset allocation for the bank is: 


$$
y^{*}=\frac{E\left(r_{p}\right)-r_{f}}{A \sigma_{p}^{2}}
$$

So the bank behavior coefficient in determining the risk aversion is as follows:

$$
A=\frac{E\left(r_{p}\right)-r_{f}}{y^{*} \sigma_{p}^{2}}
$$

Where:

$$
\begin{array}{ll}
A & =\text { Coefficient of Bank Risk Aversion } \\
E\left(r_{p}\right)-r_{f}= & \text { (the difference between expected return of risky portfolio with the return of } \\
& \text { non-risky assets) } \\
= & \text { Total risky bank (other than SBI and SUN) } \\
y^{*} & \text { Variance of asset returns } \\
\sigma_{p}^{2} &
\end{array}
$$

\subsubsection{Risk Level Indicator in the Banking Sector}

In addition to using indicators of risk perception which has been described above, in this study other risk indicator is also employed: the risk level indicators of banking sector. If a company's market value is lower than its liabilities, the company is then declared bankrupt/ default. By using this concept, the risk of a company (including banks), can be identified by utilizing the information on how far the distance between the of ratio condition of market value of bank assets to the bank liabilities that exist within the default condition occurs. Using the theory developed by Merton (1974) to determine the Distance to Default, Vassalou and Xing (2004) employ the following formula:

$$
D D_{t}=\frac{\ln \left(V_{A, t} / X_{t}\right)+\left(\mu-\sigma_{A}^{2}\right) T}{\sigma_{A} \sqrt{T}}
$$

Where:

$$
\begin{aligned}
& D D_{t}=\text { Distance to default } \\
& V_{A, t}=\text { The market value of assets } \\
& X_{t}=\text { Total Liabilities } \\
& \mu=\text { Average of Asset Value Growth } \\
& \sigma_{A}=\text { Standard deviation of the asset market value } \\
& T=\text { Due date of corporate loan }
\end{aligned}
$$


$D D$ defines the standard deviation from the mean value required by the ratio of market asset value against the liabilities for a company which experience default or may be declared default (Vassalou and Xing, 2004). Bank is a type of company under certain very strict rules and has different structure of assets and liabilities compared with other corporate in general. $A$ bank will have a much greater liabilities than other companies because it manages funds from public. As the consequence, the calculations used to determine the $D D$ indicator of a bank should also be adjusted. Since the method proposed by Vassalou and Xing (2004) is a generally used method by companies and not specifically used for the bank, the DD value calculation formula must be modified as proposed by (Chan-Lau and Sy, 2007) as follows

$$
D D_{t}=\frac{\ln \left(V_{A, t} / \lambda X_{t}\right)+\left(\mu-\sigma_{A}^{2}\right) T}{\sigma_{A} \sqrt{T}}
$$

Where: $D D_{t}=$ Distance to Capital

$$
\lambda=\frac{1}{1-P C A R_{i}}
$$

$P C A R=$ Minimum $C A R$ (Capital Adequacy Ratio) in accordance with banking regulation

Based on the equation (24), implicitly in equation (23), it shows the value of $\lambda=1$. The implication of equation (24) is no longer the value of distance to default but the distance to the capital which is the size of a bank's solvency.

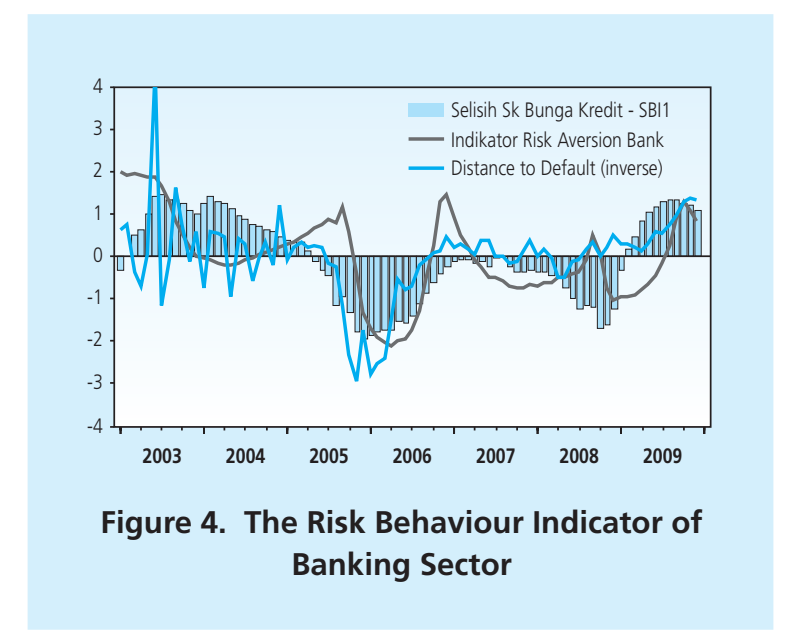


Figure 4 shows the results of the calculation of risk behavior indicators. It can be seen that the risk behavior of economic actors (risk aversion indicator) and the risk level in the banking sector (distance to default - inverse) tend to be low at the risk premium, which is estimated from the difference between credit interest rate and policy interest rate policy (SBI 1 bulan), high and vice versa. This condition indicates that the economic actors from banking sector will respond to constraint of monetary policy by allocating the managed funds to a portfolio which is relatively less risky. Meanwhile, when the monetary policy interest rates tend to be low, high risk premium is capable to reduce the high effect of their risk perception on their behavior in the allocation of funds managed.

\subsection{Stance Indicator of Monetary Policy}

For that the equation (12) can be estimated, it requires stance indicator of monetary policy. Monetary policy stance, used as explanatory variables for the short-term dynamics of banking credit in this research, is the difference between actual policy interest rate (SBI rate) with the estimation using the Monetary Policy Rules. Following Juhro (2009), this study is using data of the monetary policy stance which is obtained based on the empirical estimation of Taylor Rules. The Taylor Rules estimation are resulted from the modified equations of classical Taylor Rules, known as the smoothing interest rules as follows (Clarida, Galli, Gertler (1997) in Juhro, (2009):

$i_{t}=0.8 i_{t-1}+0.2\left[6+1.1\left(\pi_{t}-\pi_{t}^{*}\right)+0.4\left(y_{t}-y_{t}^{*}\right)\right]$

Where:

$i_{t}=$ Interest rate of optimal monetary policy

$\pi_{t}=$ Actual Inflation

$\pi_{t}^{*}=$ Inflation Target

$y_{t}=$ Actual GDP

$y_{t}^{*}=$ Potential GDP which is calculated using Hodrick-Prescot Filter

Furthermore, based on the results of these estimates, it will be then known, the interest rates suggested by Taylor Rules. While the monetary policy stance is the difference between the actual interest rate obtained on the basis of Taylor Rules. Some economists use a different form as a measure of the monetary policy stance which is based on Taylor Rules. This study uses a dummy variable as a reflection of the stance of strict or loose monetary policy. In this case, the difference of actual interest rate which is in the range of $+/-25$ bps consider to reflect the 
normal policy stance, while a greater/lesser difference is from the range reflects the policy stance that tends to be strict/ loose.

\section{RESULT AND ANALYSIS}

Prior to conducting the empirical model estimation and hypotheses testing, in order to test the existence and impact of risk in the transmission mechanism of monetary policy through bank credit channels in Indonesia, the testing the feasibility of the data used is employed to test the specified empirical model. The experiments conducted are the unit root test, the test on the existence of co-integration or the long-term relationship in the balance between credit and GDP. Data stasionarity test data and co-integration tests show a result that credit and GDP are co-integrated, so the analysis with using the Error Correction Model (ECM) can be used. Based on the results of co-integration test, it shows that the three types of credit (consumption, working capital, and investment) have a long term relationship with the economy. Thus, there is a long-term relationship between banking credit with the economic development. This analysis result also justifies the existence of the economic impact from banking credit.

The next stage is to analyze the relationship between the risk and the short-term dynamics of bank credit. Then, based on the impact of the interaction between the monetary policy stance with the risk variables, an analysis is conducted on the existence of the risk in the transmission mechanism of monetary policy in Indonesia. The estimation results of Vector Error Correction Model (VECM) concluded that the credit is not a weakly exogenous variable to GDP, so that there is feedback that occurs from changes of credit to the dynamics of GDP. Related to the focus of this study, only the empirical findings regarding the endogeneity of the credit will be reviewed in more depth, as presented in 1.

From table 1, it can be seen that the coefficient of short-term adjustment towards the long-term equilibrium (ECT/Error Correction Term) in all three credit models shows a negative sign and significant at the $99 \%$ confidence level. These results show that the model used is quite stable and correspond to the theoretical foundations. The coefficient ECT for short-term dynamics of the GDP log also showed a positive and significant result. Meanwhile, in the perspective of modeling goodness of fit, the determination coefficient shows a value within the range of 0.33 to 0.52 which is good enough for a model that uses first difference data. The F-test result also showed that all the equations resulted from the estimation are significant in 99 percent confidence level. 


\begin{tabular}{|c|c|c|c|}
\hline Independent Variable & $\begin{array}{l}\text { Investment Credit } \\
\text { [Dlog(CR_INV)] }\end{array}$ & $\begin{array}{l}\text { Working Capital Credit } \\
\text { [Dlog(CR_MK)] }\end{array}$ & $\begin{array}{l}\text { Consumption Credit } \\
\text { [Dlog(CR_KON)] }\end{array}$ \\
\hline $\mathrm{ECT}(\alpha)$ & $\begin{array}{c}-0.082055 \\
{[-3.91674]^{* * *}}\end{array}$ & $\begin{array}{c}-0.293294 \\
{[-5.08903]^{* * *}}\end{array}$ & $\begin{array}{c}-0.091933 \\
{[-2.94792]^{* * *}}\end{array}$ \\
\hline Stance ${ }^{+}$ & $\begin{array}{l}-0.002575 \\
{[-0.21983]}\end{array}$ & $\begin{array}{l}-0.013970 \\
{[-1.20977]}\end{array}$ & $\begin{array}{c}0.012844 \\
{[1.02093]}\end{array}$ \\
\hline Stance- & $\begin{array}{l}0.028623 \\
{[1.99965]^{* *}}\end{array}$ & $\begin{array}{c}0.030163 \\
{[2.43362]^{* * *}}\end{array}$ & $\begin{array}{c}0.023414 \\
{[1.75151]^{\star}}\end{array}$ \\
\hline DD & $\begin{array}{l}-0.001531 \\
{[-1.16145]}\end{array}$ & $\begin{array}{c}-0.002443 \\
{[-1.96550]^{\star}}\end{array}$ & $\begin{array}{l}-0.000502 \\
{[-0.38484]}\end{array}$ \\
\hline A & $\begin{array}{c}0.002996 \\
{[0.24890]}\end{array}$ & $\begin{array}{c}0.024078 \\
{[1.89834]^{*}}\end{array}$ & $\begin{array}{c}0.025623 \\
{[2.08346]^{\star *}}\end{array}$ \\
\hline Stance ${ }^{+*} \mathrm{~A}$ & $\begin{array}{l}-0.006795 \\
{[-0.52006]}\end{array}$ & $\begin{array}{c}-0.023959 \\
{[-1.76619]^{\star}}\end{array}$ & $\begin{array}{c}-0.030875 \\
{[-2.39797]^{* * *}}\end{array}$ \\
\hline Stance *A & $\begin{array}{c}-0.032355 \\
{[-1.91202]^{*}}\end{array}$ & $\begin{array}{c}-0.043594 \\
{[-2.45359] * * *}\end{array}$ & $\begin{array}{c}-0.050885 \\
{[-3.18399]^{* * *}}\end{array}$ \\
\hline Stance ${ }^{+}$DD & $\begin{array}{c}0.001991 \\
{[1.25322]}\end{array}$ & $\begin{array}{c}0.004052 \\
{[2.57037]^{* * *}}\end{array}$ & $\begin{array}{l}0.000966 \\
{[0.58502]}\end{array}$ \\
\hline Stance ${ }^{*}$ DD & $\begin{array}{c}-0.003427 \\
{[-1.86661]^{\star}}\end{array}$ & $\begin{array}{c}-0.003327 \\
{[-2.03648]^{\star *}}\end{array}$ & $\begin{array}{l}-0.001984 \\
{[-1.09173]}\end{array}$ \\
\hline $\begin{array}{l}R^{2} \\
\text { F-test }\end{array}$ & $\begin{array}{l}0.406906 \\
3.185347^{* * *}\end{array}$ & $\begin{array}{c}0.523314 \\
5.097017 * * *\end{array}$ & $\begin{array}{c}0.339990 \\
2.391671 * * *\end{array}$ \\
\hline
\end{tabular}

Source: Data Processing Results

Note: The figures in brackets are the results of t-count, *** Significant at $\alpha 1 \%$, ** Significant at $\alpha 5 \%$, ${ }^{*}$ Significant at $\alpha 10 \%$, Stance $^{+}=$Strict Monetary Policy, Stance ${ }^{-}=$Loose Monetary Policy

\subsection{The Impact of Risk Behavior at the Short-Term Credit Dynamic}

The calculation result of partial impact of the risk behavior variables on the short term credit dynamic can be observed in Table 2 . The results of calculation and statistical tests showed that when the monetary policy is loose there is a significant influence of risk perception on banking sector economic actors (A) and the risk level of banking sector (DD) on the dynamics of short-term credit distributed by the banking sector (excluding the impact of variable $A$ for the Working Capital Loan). When the monetary policy is strict, only the influence of variables of the risk level in the banking sector in the model of working capital loans which is considerably significant. These results confirm that in the short term there is a significant influence from the risk perception variable of economic actors and the risk level of the banking sector on the dynamics of bank credit in Indonesia. 


\begin{tabular}{|c|c|c|c|}
\hline \multicolumn{2}{|c|}{ Stance of Strict Monetary Policy } & Standard error & $t$ - value \\
\hline$\frac{\partial C R^{I N V}}{\partial A}$ & -0.003799 & 0.00526 & -0.72224 \\
\hline$\frac{\partial C R^{K M K}}{\partial A}$ & 0.000119 & 0.00568 & 0.0205951 \\
\hline$\frac{\partial C R^{K O N}}{\partial A}$ & -0.005252 & 0.00504 & -1.04026 \\
\hline$\frac{\partial C R^{I N V}}{\partial A}$ & 0.00046 & 0.00098 & 0.469388 \\
\hline$\frac{\partial C R^{K M K}}{\partial A}$ & -0.00243 & 0.00105 & $-2.32667 * *$ \\
\hline$\frac{\partial C R^{K O N}}{\partial A}$ & 0.000464 & 0.0093 & 0.498925 \\
\hline \multicolumn{4}{|c|}{ Stance of Loose Monetary Policy : } \\
\hline$\frac{\partial C R^{I N V}}{\partial A}$ & -0.029359 & 0.01212 & $-2.42236^{* * *}$ \\
\hline$\frac{\partial C R^{K M K}}{\partial A}$ & -0.019516 & 0.01322 & -1.47625 \\
\hline$\frac{\partial C R^{K O N}}{\partial A}$ & -0.025262 & 0.0119 & $-2.12286 * *$ \\
\hline$\frac{\partial C R^{I N V}}{\partial A}$ & -0.00496 & 0.00118 & $-4.20169 * * *$ \\
\hline$\frac{\partial C R^{K M K}}{\partial A}$ & -0.005770 & 0.0012 & $-4.80833 * * *$ \\
\hline$\frac{\partial C R^{K O N}}{\partial A}$ & -0.00249 & 0.00098 & $-2.53673 * * *$ \\
\hline
\end{tabular}

Source: Data Processing Results. *** Significant at $\alpha 1 \%,{ }^{* *}$ Significant at $\alpha 5 \%$, * Significant at $\alpha 10 \%$

Furthermore, based on the direction of coefficient from the estimation results that pass the statistics test, the risk perception variables of economic actors in the banking sector have a negative and significant impact for the two types of credit (investment and consumption credit.) Economically, during the interaction with a loose monetary policy stance, if there is an increase in risk perceptions of economic actors in the banking sector, it will lower the percentage of credit changes given for both types of credit, ceteris paribus. Implications of these findings are the need for understanding of the direction of the level of risk perceptions of economic actors in the banking sector by monetary policy makers when running an expansive monetary policy, because if there is an increase in risk perception of the current economic actors who run an expansive monetary policy, then the impact will reduce or even reverse the impact of monetary policy that run on the economy through a reduction in credit expansion. 
Furthermore, the variable of rate risk of banking sector (which interacts with loose monetary policy stance) has a negative and significant influence direction, which means that at the time of the an expansive monetary policy takes place, the lower the risk of the banking sector (DD rises), it will cause a decline in percentage of the bank credit growth distributed on three types of credit, ceteris paribus. The implications of this empirical finding are inconsistent with the results from the theoretical analysis conducted in this study. This phenomenon requires a deeper analysis for the explanation. The temporary explanation of this condition is the interaction between banking sector risks that is pro-cyclical (+) with monetary policy that is contra-cyclical $(-)$, causing reversal of the positive impact of the reduction of risk in banking sector to the credit growth.

The original argument that supports the cause of this condition is as follows. First, the anomalies in the Indonesian banking industry, where although the Indonesian banking sector tends to be inefficient and have a high risk level, but still has a high enough profit margin. Second, issues related to the persistence of excess of liquidity and pro-cyclical behavior of loans distributed by the banking sector (Bank Indonesia, 2010). The loose monetary policy stance (forward looking) is a signal to the perpetrators of banking on the direction of the economy that tend to deteriorate, in the manner that the economic actors in the banking sector tend not to expand credit, but retain the amount of liquidity in the form of liquid, risk free portfolio. Third, empirical findings related to competitive behavior in the banking industry in Indonesia (Ariefianto, 2010). The study found that banks that have a high non performing loans (NPLs) ratio, tends to apply credit expansion to lower its NPL ratio when the DD value is low (high risk).

Except for the banking sector risk impact on the working capital loans, the impact of the risk variables is not significant to the dynamics of short-term credit channeled by banks during strict monetary policy. The explanation for this condition is that the counter-cyclical monetary policy indicates that the economy is in booming when the policy is strictly implemented, while the risk perceptions of economic actors and the risk level in the banking sector tends to be low when the economy is in boom condition. Consequently, if there is an increase in risk perceptions of economic actors and the in the risk level in the banking sector under a stable economic condition, it tends to not affect the dynamics of short-term loans distributed by the banking sector. These results indicate that the effect of risk behaviors has a non-linier impact during a strict monetary policy, or it is predictable that the risk behavior will influence the dynamics of short-term loans after passing a certain threshold value (Li and St-Amant, 2010). Further research is needed to obtain an explanation of the phenomenon.

Related to the dynamics of working capital credit, the impact of the risk level in the banking sector is significant, but the risk perception impact on the economic actor is not 
significant both at the time of strict or loose monetary policy. This is possible because the working capital loan is a long-term loan between banks and customers. Thus, there is a banking relationship in the case of working capital loans, which lead to the risk perception of the wellknown banking players and which is not a determining factor to the increase of bank credit. In contrast, the risk level in the banking sector is a factor affecting the dynamics of short-term working capital loans. This shows the indication of the behavior of credit supply which tends to fall when the economy is under pressure (while running loose monetary policy), whereas at the time of strict monetary policy, the increase interest rates will reduce the demand for working capital credit from the business people.

Overall, based on the findings and empirical analysis that has been done, the risk level in the banking sector (which interacts with the monetary policy stance) has a significant impact in the dynamics of short-term bank credit at the time of loose monetary policy. In the current strict monetary policy, the risk level of banking sector is only significant for the model of working capital loans. The risk perceptions of economic actors in the banking sector is not significant for all types of credit under a stringent policy stance, while during a loose monetary policy, the impact is significant on consumption credit and investment credit.

\subsection{Impact of Monetary Policy Stance in the Dynamics of Short-Term Loans}

Based on the estimation presented in table 1, the results of calculations for the impact of monetary policy stance that interact with the risk behavior variables are as follows:

\begin{tabular}{|c|c|c|c|}
\hline & Investment Credit & Working Capital Credit & Consumption Credit \\
\hline$\frac{\partial C r^{i}}{\partial \text { Stance }^{+}}$ & $\begin{array}{l}0.004322 \\
(0.00824)\end{array}$ & $\begin{array}{l}-0.00789 \\
(0.00879)\end{array}$ & $\begin{array}{l}-0.00548 \\
(0.00816)\end{array}$ \\
\hline$\frac{\partial C r^{i}}{\partial \text { Stance }}$ & $\begin{array}{c}-0.01786 \\
(0.00945)^{*}\end{array}$ & $\begin{array}{c}-0.02453 \\
(0.00993)^{* * *}\end{array}$ & $\begin{array}{c}-0.02876 \\
(0.00929) * * *\end{array}$ \\
\hline
\end{tabular}

Source: Results of Data Processing. ${ }^{* *}$ Significant at $\alpha 1 \%, * *$ Significant at $\alpha 5 \%$, * Significant at $\alpha 10 \%$

Note: Figures in brackets are the standard error of the calculation of the impact of monetary policy stance (using the average sample value on each risk variables used).

The results of calculations presented in Table 3 show that only a loose monetary policy stance has a significant influence on the dynamics of short-term bank credit. Based on the coefficient obtained, the impact of loose monetary policy stance on bank loan growth will be lower than at the time when monetary policy stance runs strictly. On the investment credit, 
under a loose monetary policy, the credit growth in investment will be at 0.01786 (1.786 percent), which is lower than the average growth of investment credit when the monetary policy is loose. That means if the average loan growth of investment is 10 percent under a nonloose monetary policy, and around $8.214 \%$ under a loose monetary policy, ceteris paribus. A similar analysis result can also be applied to working capital loans and consumption loan. Under a loose monetary policy, the growth of working capital loans will be by 2.453 percent, lower than average growth in working capital loans. And under a loose monetary policy, credit growth in consumption will be by 2.876 , percent lower than the growth in consumer credit.

The implications of empirical findings for the impact of strict monetary policy stance is monetary contraction when interacting with both risk behavior variables that are used not to affect the dynamics of short-term credit to the three types of loans distributed by banks. Those empirical findings are inconsistent with the theory which implies that monetary policy which interacts with the risk variables will affect significantly the short-term credit dynamics. These findings indicate a risk variable impact which eliminates the role of monetary policy in contracting the economy. Contractive monetary policy is applied when under the economic boom, while at the same time the risk perception of economic actors and the risk level in the banking sector tends to be low. As a result, monetary tightening, which should be contracting the economy through credit channels, is losing its impact. The empirical findings indicate that although the central bank imposes a strict monetary policy, it will not be restricting enough to contract the economy through a reduction in bank credit growth.

Likewise, a loose monetary policy, which interacts with the risk behavior variable, has a negative and significant impact for the three types of bank loans extended. These empirical findings correspond to the theory that shows the existence of significant impact from a loose monetary policy that interacts with risk behavior variables. The direction of coefficient relationship of the estimation results shows a negative relationship. These results show that the expansive monetary policy can not improve the growth of bank credit. Under an expansive monetary policy (enacted with the aim to stimulate the economy under pressure), the risk perception of economic actors and the risk level in the banking sector tends to be high (the average is higher during the analysis period). As a result, a loose monetary policy can not boost the economy through the increase of bank loans, in contrary it has a reversing effect by reducing the credit growth which can then be later contracting the economy. These findings indicate that at the time of the easing of monetary policy implemented by the central bank, in an effort to drive the economy, the banking sector economic actors tend to have a high risk perception. Thus, banks will establish a high risk premium in the loan interest rate offered by the banking sector. In other words, there is rigidity in interest rates which is applicable at the time of monetary 
expansion. Another explanation that can be delivered is that the tendency of economic actors in the banking sector to see the loose monetary policy as an indication that the economy is experiencing pressure. As a result, banks become more selective in allocating their assets to the credit sector.

\section{v. CONCLUSION}

Some of the main conclusions resulted from this research is that risk perceptions of economic actors and the risk level in the banking sector have a significant role in transmitting monetary policy through credit channels in Indonesia. The variable of risk perceptions of economic actors and the risk level in the banking sector when interacting with the monetary policy stance lead to the reversal of direction of a loose impact monetary policy. Loose monetary policy stance could be a signal for economic players in the banking sector as the economy is heading toward an adverse development. Conversely, a strict monetary policy stance for the economy to contract the economy through the bank credit channels become ineffective when interacting with the risk perception variables of economic actors and the risk level in the banking sector. This is probably due to the impact of risk behaviors that eliminate the role of monetary policy in contracting the economy.

Indirectly, the findings also conclude that for the case of Indonesia, a loose monetary policy stance has the effect that causes the perpetrators in the banking sector tend to be more risk averse. These findings is different from the research results presented by Taylor (2009) for the case of developed countries, whereas in developed countries an easing in monetary policy causes the economic actors in the financial sector to become more risk takers. The analysis also shows that there are indications of non-symmetrical impact of strict and loose monetary policy during the interaction with the risk behavior variables. Under a strict monetary policy, risk behaviors tend to eliminate the impact of monetary tightening on the dynamics of short-term bank credit. At the time of loose monetary policy, the interest rate cut under the central bank's policy is not able to reduce the bank loan rates in order to encourage the increase of credit, as a result of a rather high-risk behavior when the economy is under the pressure.

Related to the empirical findings above, there are some fundamental policy implications that lead to the need for the integration of monetary policy and macro-prudential in the financial sector, as follows. First, Bank Indonesia, as the monetary and banking authority, need to take into account the role of risk perceptions of economic actors and the risk level in the banking sector in the formulation of monetary policy and financial system in Indonesia. This research can be basically used as one starting point to take in account the risk behavior in the financial 
sector within the monetary policy reaction function, which is expected to address the issue of the (pro)cyclicality of economy in general. Second, within the context to promote the deepening and the expansion of the role of financial markets, Bank Indonesia needs to do more in-depth study related to the impact of dynamics in the financial sector on the effectiveness of running monetary policy. Third, in line with a very close interaction between the dynamics (stability) of the monetary sector and financial, sector, the strengthening of policy coordination is highly demanded from the relevant authorities to carry out the monetary policy and financial policy entirely.

In the end, that the research may be a mere preliminary study. Analytically, this initial research can only produce a new evidence of the presence of risk channel in the transmission mechanism of monetary policy in Indonesia, at the very least at the time when the loose monetary policy is running. The facts obtained are still in black box status, and the process and flow of the transmission mechanism of monetary policy through the risk channel itself has not been able to put things clear by these finding. Therefore, in the future, more researches are needed to look deeper into the phenomenon found in this black box. In addition, the methodological improvements can be made, especially related to the selection of alternative indicators of risk behavior, the disaggregated assessment of risk behavior indicators that refers to an individual or a group of banks, as well as the possibility of the presence of feedback mechanisms between the two variables used in risk behavior. Those completions are expected to answer several empirical questions that can not be explained well in this study. 


\section{REFERENCES}

Adrian, Tobias, and Hyun Song Shin. (2009), Prices and Quantities in the Monetary Policy Transmission Mechanism, International Journal of Central Banking, 5(4).

Ariefianto, Doddy M, (2010), Perilaku Persaingan Industri Perbankan di Indonesia Pasca Krisis (Analisa Dengan Pendekatan Teori Oligopoli dan Ekonometrika Panel Data Pada Periode 2002 - 2008), Desertasi Doktor Bidang Ilmu Ekonomi. Fakultas Ekonomi Universitas Indonesia. Bank Indonesia, (2010), Response Kebijakan Moneter di Tengah Krisis Global, Laporan

Perekonomian Indonesia Tahun 2009, Bank Indonesia.

Bernanke, Ben. S, dan Alan S. Blinder (1988), Credit, Money and Aggregate Demand, The American Economic Review, Vol 78, no. 2. American Economic Association.

Bernanke, Ben. S dan Mark Gertler (1995), Inside the Black Box: The Credit Channel of Monetary Transmission Mechanism, Journal of Economic Perspectives, Vol 9 No.4. American Economic Association.

Bernanke, Ben S, Mark Gertler dan Simon Gilchrist (1996), The Financial Accelerator and Flight to Quality, The Review of Economics and Statistics, Vol 78.

Bodie, Zvi, Alex Kane dan Alan J. Marcus (2009), Investment $8^{\text {th }}$ Ed. Mc Graw-Hill International, Singapore.

Borio, Claudio dan Haibin Zhu (2008), Capital Regulation, Risk Taking and Monetary Policy: A Missing Link in the Transmission Mechanism?, BIS Working Paper no 268. Bank for International Settlement, Basel - Switzerland.

Chan-Lau, Jorge A, dan Amadou N.R. Sy (2007), Distance to Default in Banking: A Bridge too Far?, Journal of Banking Regulation, Vol 9 No. 1. Palgrave Mc Milan.

Diamond, Douglas W, dan Raghuram G. Rajan, (2006), Money in Theory of Banking, The American Economic Review, Vol 96 No.1, American Economic Association.

Diamond, Douglas W, dan Raghuram G. Rajan, (2001), Liquidity Creation and Financial Fragility:

A Theory of Banking, The Journal of Political Economy, Vol. 109 No. 2. The University of Chicago Press.

Diamond, Douglas W, dan Raghuram G. Rajan, (2000), A Theory of Bank Capital, The Journal of Finance Vol 55 No. 6, American Finance Association.

Disyatat, Piti (2010), Bank Lending Channel Revisited, BIS Working Paper No. 297. BIS Monetary Policy Department, Basel-Switzerland. 
Enders, W., (2004), Applied Econometric Time Series, New York: John Wiley \& Sons

Escandon, Julio R, Alejandro Diaz-Bautista, (2000), A Simple Dynamic Model of Credit and Aggregate Demand, El Collegio De La Frontera Norte, Working Paper No.18..

Freixas, Xavier dan Jose Jorge, (2008). The Role of Interbank Market in Monetary Policy: A Model with Rationing, The Journal of Money Credit and Banking, September.

Gambacorta, Leonardo (2009), Monetary Policy and the Risk Taking Channel, BIS Quarterly Review, Desember 2009. Bank for International Settlement, Basel.

Goeltom, Miranda. S, Solikin M. Juhro dan Firman Mochtar (2009), Indonesian Monetary Policy

Transmission Mechanisms and the Role of Risk Perception, Research Notes, Bank Indonesia, March.

Goodhart, C.A.E dan D.P. Tsomocs, (2007), Analisys of Financial Stability, Bank of Canada Conference "Developing a Framework to Asses Financial Stability" Ottawa, Canada, 7-8 November.

Juhro, Solikin M. (2009)," Telaah Policy Rules di Indonesia, Research Notes, Bank Indonesia, Maret.

Mishkin, Frederick S. (2009), Is Monetary Policy Effective During Financial Crisis?, NBER Working Paper No. 14678.

Merton, Robert C. (1974), On the Pricing of Corporate Debt: the Risk Structure of Interest Rates, Journal of Finance Vol. 29.

Nier, Erlend dan Lea Zicchino, (2008), Bank Losses, Monetary Policy and Financial StabilityEvidence From Interplay in Panel Data, IMF Working Paper WP/08/232.

Li, Fuchun dan Pierre St-Amant (2010), Financial Stress, Monetary Policy and Economic Activty, Bank of Canada Working Paper 2010-12, May.

Taylor, John B. (2009), The Financial Crisis and Monetary Response: An Empirical Analysis of What Went Wrong, NBER Working Paper Series No. 14631.

Tieman, Alexander F, dan Andrea M Maechler, (2009), The Real Effects of Financial Sector Risk, IMF Working Paper WP/09/198, IMF Washington.

Van Den Heuvel, Skander J, (2007). The Bank Capital Channel of Monetary Policy, Bank of Canada Conference "Developing a Framework to Asses Financial Stability" Ottawa, Canada, 7-8 November.

Vassalaou, Maria dan Yuhang Xing (2004), Default Risk in Equity Return, The Journal of Finance, Vol 59 No, 2. April.

Wooldridge, Jeffery M. (2006), Introductory Ecoometrics: A Modern Approach $3^{\text {rd }}$ Ed. Thompson South-Western Publishing. USA. 